\title{
Curcumin effects in inducing mRNA gene cathelidicin antimicrobial peptide in Balb/c mice infected with Salmonella typhi
}

\author{
Ami Febriza, ${ }^{1}$ Rosdiana Natzir, ${ }^{2}$ Mochammad Hatta, ${ }^{3}$ Cuno S.P.M Uiterwaal, ${ }^{4}$ Suryani As'ad, ${ }^{5}$ Budu, ${ }^{6}$ \\ Gemini Alam, ${ }^{7}$ Vivien Novarina Kasim, ${ }^{8}$ Hasta Handayani Idrus ${ }^{9}$
}

${ }^{1}$ Department of Physiology, Faculty of Medicine, University of Muhammadiyah Makassar, Makassar; ${ }^{2}$ Biochemistry Department; ${ }^{3}$ Molecular Biology and Immunology Laboratory, Faculty of Medicine, Hasanuddin University, Makassar, Indonesia; ${ }^{4}$ Julius Centre for Health Sciences and Primary Care, University Medical Center, Utrecht, The Netherlands; ${ }^{5}$ Clinical Nutritional Department; ${ }^{6}$ Department of Ophtalmology, Faculty of Medicine; ${ }^{7}$ Department of Pharmacognosy, Faculty of Pharmacy, Hasanuddin University, Makassar; ${ }^{8}$ Faculty of Medicine, Gorontalo State University, Gorontalo; ${ }^{9}$ Department of Microbiology, Faculty of Medicine, University Muslim Indonesia, Makassar, Indonesia

\author{
Correspondence: Ami Febriza, Department of Physiology, Faculty of \\ Medicine, University of Muhammadiyah Makassar, J1. Sultan \\ Alauddin No. 259, Makassar, South Sulawesi, Indonesia. \\ Tel.: 085256655987 / 087840485864 (WA). \\ E-mail: amifebriza@med.unismuh.ac.id
}

Key words: Curcumin; CAMP; salmonella; colony count.

Acknowledgments: Authors would like to thank Rommy Usman, Mus, Wani and Mark (Molecular Biology and Immunology Laboratory for Infection Diseases, Faculty of Medicine, Hasanuddin University, Makassar, Indonesia) who helped in the implementation of our research activities. This research was financially supported by the BUDI-DN LPDP, Indonesia. The authors also acknowledge the University of Muhammadiyah Makassar for supporting this publication.

Contributions: All authors have made substantial contributions to conception and design, or acquisition of data, or analysis and interpretation of data; have been involved in drafting the manuscript or revising it critically for important intellectual content; and have given final approval of the version to be published.

Conflict of interest: The authors declare conflict of interest.

Funding: This research was financially supported by BUDI-DN LDPD.

Ethics approval: This study was approved by the Health Medical Research Ethics Committee at the Faculty of Medicine, Hasanuddin University (Makassar, Indonesia), with registration number 901/H4.8.4.5.31/PP36-KOMETIK/2018 on October 31, 2018.

Received for publication: 4 March 2020.

Accepted for publication: 18 July 2020.

${ }^{\circ}$ Copyright: the Author(s), 2020

Licensee PAGEPress, Italy

Journal of Biological Research 2020; 93:8942

doi:10.4081/jbr.2020.8942

This article is distributed under the terms of the Creative Commons Attribution Noncommercial License (by-nc 4.0) which permits any noncommercial use, distribution, and reproduction in any medium, provided the original author(s) and source are credited.

\begin{abstract}
Efforts to combine various herbal compounds are made in the wake of numerous cases of antibiotic resistance. Curcumin is an active compound found in herbal plants. It has an antimicrobial effect that can induce the expression of the mRNA Cathelidicin Antimicrobial Peptide (CAMP) gene and eradicate bacteria. Twenty-five adult BALB/c mice, aged 8-12 weeks and weighing 30-40 grams, were induced with Salmonella typhi at the intraperitoneal cavities. They were randomly allocated in equal blocks to receive CM200 (200 mg/kg of curcumin), CM400 (400 mg/kg of curcumin), CM200+vit D (200 mg/kg of curcumin with vitamin $\mathrm{D})$, and positive control or negative control for 5 days. Mice were then maintained for 3 weeks to count the colonies in the post-intervention period and the level of the mRNA CAMP gene. Real-time PCR was used to measure the expression of the CAMP gene. The level of the mRNA CAMP gene expression significantly increased in CM200 (2.01 \pm 0.75$)$ and CM400 (4.06 \pm 0.68$)$, p difference $<0.0001$. The highest increase of the CAMP gene expression was observed in CM200+vit D $(5.47 \pm 0.53)$, p difference $<0.0001$. Curcumin increased the expression of the mRNA CAMP gene.
\end{abstract}

\section{Introduction}

Typhoid fever is characterized by a prolonged heat wave, followed by bacteremia and bacterial invasion of Salmonella typhi, as well as multiplication into mononuclear phagocytic cells of the liver, spleen, lymph nodes, and intestinal Peyer's patches. ${ }^{1}$ Typhoid fever occurs worldwide, but it especially does in developing countries with poor sanitation. The incidence of typhoid fever is high ( $>100$ cases per 10,000 population per year) in Central Asia, South Asia, Southeast Asia, Africa, Latin America, and Oceania (except for Australia and New Zealand), which is in contrast to the comparatively low rates $(<10$ cases per 10,000 population per year) seen in the rest of the world. ${ }^{2,3}$ Each year typhoid fever affects 21.6 million people (3.6/1,000 population) with a mortality rate of 200,000/year. Eighty percent of cases of typhoid fever in the world occur in Bangladesh, China, India, Indonesia, Laos, Nepal, and Pakistan.

Chloramphenicol was the first antibiotic introduced into treatment for typhoid in 1948 and became a treatment of choice. ${ }^{4,5}$ The 
strains of Salmonella typhi resistant to chloramphenicol, ampicillin, and trimethoprin are known as MDR (Multiple Drug Resistant) Salmonella typhi, which first occurred in $1974 .{ }^{6,7}$ To date, Salmonella typhi is also widely reported to be resistant to second-line therapy such as third-generation cephalosporin and quinolone class antibiotics. ${ }^{8-11}$ Such drug resistance is a serious threat, particularly in regions with limited resources, because it requires fairly expensive replacement treatment for typhoid fever. Serious effort is required by the medical community to get correct diagnoses, in which case treatment or vaccination can be used to control the spread of drug resistance for typhoid. ${ }^{12}$

Curcumin has anti-inflammatory and anti-microbial properties. It can induce the expression of Cathelicidin Antimicrobial Peptide (CAMP) and eradicate bacteria. Additionally, curcumin can enhance the mRNA expression of CAMP so as to increase the levels of cathelicidin in the network. ${ }^{13}$ Cathelicidin is a type of antimicrobial peptide. ${ }^{14}$ It is a small molecular peptide (consisting of $12-$ 100 amino acids) which has broad-spectrum antimicorbial activity and is estimated to have a function in the natural immune system as the first defense against microorganisms. ${ }^{15}$

Given the high morbidity of typhoid fever, a growing number of occurrences of relapse, and resistance in Salmonella typhi bacteria, attempts to combine the antimicrobial agent and herbal remedies have gained much interest. The objective of this work was to analyze mRNA CAMP gene expression following administration of curcumin in mice infected with Salmonella typhi.

\section{Materials and Methods}

An experimental design was used to study the effectiveness of curcumin in inducing mRNA gene CAMP and suppressing the growth of Salmonella typhi strain in BALB/c mice.

\section{Curcumin}

Curcumin was purchased from Merck (curcumin for synthesis, with chemical formula [4- $\left.(\mathrm{OH})-3-\left(\mathrm{CH}_{3} \mathrm{O}\right) \mathrm{CH}_{3} \mathrm{CH}=\mathrm{CHCO}\right]_{2} \mathrm{CH}_{2}$, also known as 1,7-Bis(4-hydroxy-3-Methoxyphenyl)-1,6-heptadiene-3,5-dione, turmeric yellow, and diferuloylmethane).

\section{Experimental animals and treatment}

Twenty-five BALB/c adult male mice (aged 8-12 weeks, weighing 30-40 grams) were kept in the Molecular Biology and Immunology Laboratory, Microbiology Department, Faculty of Medicine, Hasanuddin University (Makassar, Indonesia), and randomly allocated to five treatment groups of equal size. All groups were intraperitoneally induced with Salmonella typhi strain thy1 $\left(3 \mathrm{ml} \times 10^{3} \mathrm{CFU} / \mathrm{mL}\right)$. The five treatment groups were as follows: curcumin dose of $200 \mathrm{mg} / \mathrm{kg}$ (CM200), curcumin dose of $400 \mathrm{mg} / \mathrm{kg}$ (CM400), curcumin dose of $200 \mathrm{mg} / \mathrm{kg}$ plus vitamin D (CM200+vit D), positive control (antibiotic levofloxacin dose of $1.95 \mathrm{mg} / \mathrm{kg}$ ), and negative control (placebo). Curcumin doses were dissolved in distilled water and given through nasogastric tube once a day for five days. Levofloxacin was obtained from Indonesian pharmacy Kimia Farma. The 750 $\mathrm{mg}$ of levofloxacin dose given to mice was obtained from multiplication with a conversion factor of 0.0026 . Based on the result, the positive control group was given a $1.95 \mathrm{mg}$ /day levofloxacin dose dissolved in distilled water through the nasogastric tube once a day for five days. Vitamin D was purchased from Merck. The $200 \mathrm{IU} /$ day dose of vitamin D given to mice was obtained from multiplication with a conversion factor of 0.0026 . Based on the result, mice was given a dose of 0.52 IU of vitamin D/day for five days. Vitamin D was dissolved in distilled water and given through the nasogastric tube.

\section{Sampling of peritoneal fluid and bacterial colony examination}

All mice were induced with intraperitoneal Salmonella typhi strain thy $1\left(3 \mathrm{~mL} \times 10^{3} \mathrm{CFU} / \mathrm{mL}\right)$. For counting the bacterial colony, sampling was taken from the peritoneal fluid. Mice were fixed in the supine position, the abdomen was cleaned with $70 \%$ alcohol, and $0.8-1 \mathrm{~mL}$ of saline was injected into the peritoneal cavity. This procedure was used to help collect fluid from the peritoneal cavity. Mice were then allowed to stand for 1 minute and then rocked slowly. Then, using a syringe, the fluid was aspirated from the peritoneal cavity in the supine position to as much as $0.5 \mathrm{~mL}$.

Bacterial colonization was examined using the pour plate method by diluting the peritoneal fluid samples of $0.5 \mathrm{~mL}$ in 4.5 $\mathrm{mL}$ of saline $(0.9 \% \mathrm{NaCl})$. Dilution was done three times to prevent too dense cultures interfering with the observations. Approximately $1 \mathrm{~mL}$ of the suspension was poured into a sterile Petri dish, then a fertilizer medium (nutrient agar) was poured at $45^{\circ} \mathrm{C}$. It was then sealed and incubated for $1-2$ days at $37^{\circ} \mathrm{C}$. The number of colonies counted is expressed by colony forming unit per $\mathrm{mL}(\mathrm{CFU} / \mathrm{mL})$. A dilution factor of $10^{-3}$ was used in calculating the estimated number of bacterial colony.

\section{Nucleic acid extraction}

Nucleic acid was extracted according to the protocol of a previous study, ${ }^{16}$ with lysing, binding, and washing being the three main steps. One hundred $\mu \mathrm{L}$ of blood sample was dissolved into L6 solution, which was developed from $120 \mathrm{~g}$ of guanidiunthyocianate in $100 \mathrm{~mL}$ of $0.1 \mathrm{M}$ Tris- $\mathrm{HCl}$ at $\mathrm{pH} 6.4,22 \mathrm{~mL}$ of EDTA at $\mathrm{pH}$ 8.0, and $2.6 \mathrm{~g}$ of Triton $\mathrm{X}-100$. After the lysing process the nucleic acid was bound to celite in $50 \mathrm{~mL}$ of $\mathrm{H}_{2} \mathrm{O}$ and $500 \mu \mathrm{L}$ of $32 \%(\mathrm{w} / \mathrm{v})$. The solution then was vortexed and centrifuged in a $1.5 \mathrm{~mL}$ Eppendorf tube at $13,000 \mathrm{rpm}$ for $15 \mathrm{sec}$. The supernatant was discarded, and the sediment left then was washed with $1 \mathrm{~mL}$ of L2 solution (guanidiumthyocianate and Tris- $\mathrm{HCl}$ at $\mathrm{pH}$ 6.4). The mixture then was vortexed and centrifuged at 13,000 rpm for $15 \mathrm{sec}$. This washing process was repeated twice and continued with $1 \mathrm{~mL}$ of $70 \%$ ethanol twice, and the last with $1 \mathrm{~mL}$ of acetone. The result was then incubated in a water-bath at $56^{\circ} \mathrm{C}$ for 10 minutes. After incubation the sample was added with $60 \mu \mathrm{L}$ of TE solution (1mM EDTA in 10 mMTris- $\mathrm{HCl}$ at $\mathrm{pH} 8.0$ ), then vortexed and centrifuged at 13,000 rpm for $2 \mathrm{~min}$ and incubated in an oven for 10 minutes at $56^{\circ} \mathrm{C}$. Following the incubation, the sample was again vortexed and centrifuged at $13,000 \mathrm{rpm}$ for $30 \mathrm{sec}$. The supernatant of this process was obtained and stored at $-80^{\circ} \mathrm{C}$ before RNA analysis.

\section{Analysis of the CAMP Gene}

mRNA CAMP expression was analyzed with Real TimeQuantitative Reverse Transcription Polymerase Chain Reaction (qRT-PCR) using SYBR Green qRT-PCR Supermix (Bio-Rad, USA) and read using RT-PCR machine (BR004129USA, BioRad Laboratories, USA). The following forward and reverse primers were used for CAMP respectively: GCCGCTGATTCTTTGACAT and GCCAAGGCAGGCCTACTACT. The GAPDH gene, as housekeeping gene, forward primer was GACCACAGTCCATGCCATCA, and the reverse primer was CATCACGCCACAGTTCC.

cDNA templates for use in real time PCR were synthesized 
from $5 \mu \mathrm{g}$ of total RNA by in vitro transcription in $20 \mu \mathrm{L}$ reaction containing $0.5 \mu \mathrm{g}$ of oligo (dT), $10 \mu \mathrm{M}$ of dNTPs, and $1 \mu \mathrm{L}$ of Superscript II Reverse Transcriptase (Invitrogen, Carlsbad, CA) at $42^{\circ} \mathrm{C}$ for $50 \mathrm{~min}$. Typical real-time PCR reaction mixture included the same amount of cDNA templates from RT, 10 pmol of each primer, $25 \mu \mathrm{L}$ of iQ SYBR Green Supermix, and sterile water in a reaction volume of $50 \mu \mathrm{L}$. The PCR conditions were as follows: 3 min at $95^{\circ} \mathrm{C}$ followed by 40 cycles at $95^{\circ} \mathrm{C}$ for $30 \mathrm{sec}, 55^{\circ} \mathrm{C}$ for 30 sec, and $68^{\circ} \mathrm{C}$ for $1 \mathrm{~min}$. Relative CAMP gene expression levels were calculated by subtracting the threshold cycle number $(\mathrm{Ct})$ of the GAPDH gene from the Ct of CAMP and raising 2 to the power of this difference. $\mathrm{Ct}$ values are defined as the number of PCR cycles at which the fluorescent signal during the PCR reaches a fixed threshold.

\section{Statistical analysis}

One-way analysis of variance (one way-ANOVA) was used to test for mean differences in age, body weight, and level of mRNA CAMP gene expression among the five groups for the baseline characteristics. This test was also used to assess mean differences for levels of mRNA CAMP gene expression and bacterial colony counts among the five groups at each time of observation. Oneway ANOVA test was followed by a Least Significant Difference (LSD) post-hoc test to identify which particular differences between groups' means were significant. A p-value of $<0.05$ was considered to be of statistical significance. The data obtained was processed using SPSS 23 (IBM Coorporation, New York, USA) for Macbook.

\section{Ethics approval}

This study was approved by the Health Medical Research Ethics Committee at the Faculty of Medicine, Hasanuddin University (Makassar, Indonesia), with registration number 901/H4.8.4.5.31/PP36-KOMETIK/2018 on October 31, 2018.

\section{Results}

Data on the characteristics of mice in the groups are shown in Table 1. No statistically significant differences were found for age, body weight, or levels of CAMP gene mRNA expression at baseline.

After five days of treatment, the level of mRNA gene CAMP expression was statistically significantly increased in CM200 $(2.01 \pm 0.75)$ and CM400 (4.06 \pm 0.68$), \mathrm{p}_{\text {difference }}<0.0001$. The highest increase of CAMP gene expression was observed in CM200+vit D (5.47 \pm 0.53 ), p difference $<0.0001$ (Table 2). CM200+vit D showed an increase of CAMP mRNA by $68.07 \%$, which was the highest expression of all groups (Table 3 ).

Bacterial colonization decreased in all groups after treatment for five days. The highest decrease in bacterial colonization was

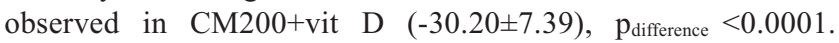
Meanwhile, for the mice treated with CM200, the bacterial colony showed a decrease of $-23.60 \pm 6.27$, almost similar to that of mice

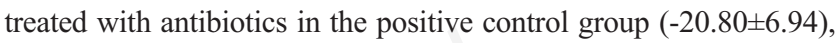
$\mathrm{p}_{\text {difference }}<0.0001$ (Table 2).

Figure 1 shows that CAMP mRNA expression was highest in the positive control group, almost equal to the expression in CM200+vit D. Increasing CAMP mRNA expression also occurred in CM400 and CM200.

\section{Discussion}

When the bacteria Salmonella typhi enter the body, they will go to the digestive tract and fall prey to macrophages. ${ }^{17,18}$ Our research is novel because it is the first intervention in vivo study to utilize the potential benefit of curcumin, combined with vitamin D, against infection of Salmonella typhi through increasing CAMP gene

Table 1. Characteristics of experimental animals at baseline.

\begin{tabular}{lccccc} 
Variable & $\begin{array}{c}\text { CM200 } \\
(\mathrm{n}=5)\end{array}$ & $\begin{array}{c}\text { CM400 } \\
(\mathrm{n}=5)\end{array}$ & $\begin{array}{c}\text { Groups } \\
\text { CM200+Vit. D } \\
(\mathrm{n}=5)\end{array}$ & $\begin{array}{c}\text { Positive control } \\
(\mathrm{n}=5)\end{array}$ & $\begin{array}{c}\text { Negative control } \\
(\mathrm{n}=5)\end{array}$ \\
\hline Age (weeks) & $9.40 \pm 1.67$ & $9.40 \pm 1.41$ & $9.40 \pm 1.67$ & $9.60 \pm 1.82$ & $9.60 \pm 1.14$ \\
Body weight (grams) & $34.10 \pm 3.95$ & $33.60 \pm 1.54$ & $31.80 \pm 1.23$ & $36.02 \pm 3.47$ & $35.42 \pm 2.23$ \\
\hline $\begin{array}{l}\text { CAMP gene expression } \\
\text { (fold change) baseline }\end{array}$ & $7.46 \pm 0.51$ & $7.14 \pm 0.63$ & $7.46 \pm 0.54$ & $7.05 \pm 0.66$ & $7.27 \pm 0.76$ \\
\hline
\end{tabular}

Values are expressed in mean \pm SD; -value of $<0.05$ is considered significant for comparison between groups with one-way ANOVA test.

Table 2. Comparison in means difference of bacterial colonization and level mRNA gen CAMP expression in each group at the time before the intervention ( $4^{\text {th }}$ day), after the intervention $\left(10^{\text {th }}\right.$ day) and 3 weeks after the intervention $\left(30^{\text {th }}\right.$ day).

\begin{tabular}{|c|c|c|c|c|}
\hline \multirow[t]{2}{*}{ Groups } & \multicolumn{2}{|c|}{$\begin{array}{l}\text { Levels of mRNA gen CAMP expression } \\
\text { (fold change) }\end{array}$} & \multicolumn{2}{|c|}{$\begin{array}{l}\text { Calculation of Bacterial Colonization S. Typhi } \\
\qquad(\mathrm{CFU} / \mathrm{mL})\end{array}$} \\
\hline & $10^{\text {th }}-4^{\text {th }}$ day & $30^{\text {th }}-4^{\text {th }}$ day & $10^{\text {th }}-4^{\text {th }}$ day & $30^{\text {th }}-4^{\text {th }}$ day \\
\hline CM200 & $2.01 \pm 0.75$ & $2.32 \pm 0.76$ & $-23.60 \pm 6.27$ & $-26.60 \pm 3.43$ \\
\hline CM400 & $4.06 \pm 0.68$ & $4.27 \pm 0.84$ & $-17.20 \pm 2.28$ & $-16.40 \pm 2.60$ \\
\hline CM200+Vit.D & $5.47 \pm 0.53$ & $5.78 \pm 0.34$ & $-30.20 \pm 7.39$ & $-30.00 \pm 7.28$ \\
\hline Positive control & $4.93 \pm 0.86$ & $4.88 \pm 0.82$ & $-20.80 \pm 6.94$ & $-22.00 \pm 6.16$ \\
\hline Negative control & $0.70 \pm 0.57$ & $1.35 \pm 0.58$ & $-15.80 \pm 8.35$ & $-20.60 \pm 7.50$ \\
\hline p-value* & 0.000 & 0.000 & 0.019 & 0.012 \\
\hline
\end{tabular}

*One-way ANOVA test, with values are mean \pm SD n $=5$; p-value $<0.05$ is considered significant. CM: curcumin; Positive control: levofloxacin. Negative control: aquades. 
expression. A limitation of our study is that the intervention was performed in an animal model. Therefore, further research in humans is recommended.

Curcumin is an active compound that is widely acknowledged as an anti-inflammatory, anticancer, and recently, antimicrobial agent.

Previous study shows that induction of CAMP by curcumin occurs in a vitamin $\mathrm{D}$ receptor-independent manner, and it does not function as ligand for the VDR. Additionally, curcumin can enhance the mRNA expression of CAMP and thus increase the levels of cathelicidin. ${ }^{13}$ It has a broad antibacterial spectrum against Grampositives and Gram-negatives as well as against fungi and parasites. Cathelicidin damages bacterial membranes by altering the membrane integrity, although some bacteria are known to have resistance to cathelicidin. Other types of bacteria such as Enterococcus faecalis, Streptococcus pyogenes, Salmonella enterica, and Proteus mirabilis can also synthesize specific proteinase to degrade cathelicidin expression. ${ }^{19}$ The findings of our study provide evidence that curcumin intervention with at $200 \mathrm{mg} / \mathrm{kg}, 400 \mathrm{mg} / \mathrm{kg}$, and 200 $\mathrm{mg} / \mathrm{kg}$, in combination with vitamin $\mathrm{D}$, can decrease bacterial colonization due to infection with Salmonella typhi, indicating that curcumin may be exerting antimicrobial activity.

Antimicrobial peptides are a group of molecules produced by cells and tissues in the body of living things that play an important role in the body's defense system, ranging from prokaryotes to humans known to produce antimicrobial peptides in the body. ${ }^{20}$ One of these antimicrobial peptides is cathelicidin, which has shown that bacterial products will increase CAMP gene expression in cultured human cells, ${ }^{21}$ indicating the role that cathelicidin plays in fighting infection.

Therapy with curcumin may therefore offer a promising alternative to antibiotics for treatment of typhoid fever. Our findings indicate that treatments with curcumin at $200 \mathrm{mg} / \mathrm{kg}$ and $400 \mathrm{mg} / \mathrm{kg} \mathrm{sig-}$ nificantly increase CAMP mRNA expression in mice infected with Salmonella typhi (Table 2). We found that curcumin with a dose of $200 \mathrm{mg} / \mathrm{kg}$ gives an average increase in the rate of mRNA gene CAMP expression by $25 \%$, while with a $400 \mathrm{mg} / \mathrm{kg}$ dose, by $50.94 \%$ (Table 3 ). Therefore, we can conclude that curcumin has the ability to enhance mRNA gene CAMP expression.

Levels of mRNA expression in the CAMP gene can also be induced by several substances. The most effective inducer of CAMP gene expression is 1,25-dihydroxyvitamin D3 [or $1,25(\mathrm{OH})_{2} \mathrm{D}_{3}$ ], which is an active form of vitamin D. $1,25(\mathrm{OH})_{2} \mathrm{D}_{3}$ works through the Vitamin D Receptor (VDR) which then binds to the vitamin D (VDRE) responsive element, about 500 bp upstream of the CAMP gene promoter. ${ }^{22,23}$ In this study, a group of mice that received curcumin therapy with vitamin D showed an increase in mean levels of
CAMP gene mRNA expression after five days of therapy (Table 2).

Vitamin D receptors are expressed in large amounts in the tumor tissue and the infected cells. Recent research has shown that the VDR and enzymes involved in the metabolism of vitamin D may damage the VDR signaling pathways. VDR expression by immune cells suggests that vitamin D affects the immune system function. More than 30 different body tissues such as those in the brain, liver and pancreas, lymphatic system, skin, gonads, and prostate consist of cells, including $\mathrm{T}$ and $\mathrm{B}$ lymphocytes, that express the VDR. The vitamin $\mathrm{D}$ receptor binds to $1,25(\mathrm{OH})_{2} \mathrm{D}_{3}$, an active form of vitamin $\mathrm{D}$, and then mediates its biological effects. ${ }^{24}$ Dendritic cells are the primary targets of the immunomodulatory activity of $1,25(\mathrm{OH})_{2} \mathrm{D}_{3}$, which inhibits the differentiation and maturation of dendritic cells. It suppresses the expression regulation of major histocompatibility complex-II (MHC-II) and costimulatory molecules (CD40, CD80, and CD86) and leads to decreased production of IL-12. In addition, $1,25(\mathrm{OH})_{2} \mathrm{D}_{3}$ increases the production of interleukin-10 (IL-10) and promotes apoptosis dendritic cells. Together, the effect of $1,25(\mathrm{OH})_{2} \mathrm{D}_{3}$ inhibits activation of $\mathrm{T}$ cells that depend on dendritic cells. ${ }^{25}$ Vitamin D has an antimicrobial effect through the modulation of the host immune response by inducing secretion of interleukin-10 (IL-10).

In this study, the mice that were given curcumin in combination with vitamin $\mathrm{D}$ for five days showed an increase in the expression of the CAMP gene mRNA by $68.07 \%$, the highest among all the groups (Table 3). Some studies found a relationship between vitamin D and antimicrobial immunity. A study of atopic dermatitis patients found that the oral administration of vitamin D at a dose of $4000 \mathrm{IU} /$ day for 21 days increased cathelicidin expression in skin lesion patients with a mild increase in normal skin patients. ${ }^{26}$ There was a modest correlation with $1,25(\mathrm{OH})_{2} \mathrm{D}_{3}$ levels, but not with $25(\mathrm{OH}) \mathrm{D}$ level. ${ }^{27} \mathrm{~A}$ study of sepsis patients saw a positive correlation between $1,25(\mathrm{OH})_{2} \mathrm{D}_{3}$ and cathelicidin levels observed in all subjects. ${ }^{28}$ Therefore, an antimicrobial effect of vitamin $\mathrm{D}$ is possible. However, it is still not clear if it can increase the level of cathelicidin in the blood because this study did not measure the level of cathelicidin in the serum. Even so, we believe that higher levels of cathelicidin in the blood will have a role in fighting an infection via innate immunity of the host.

\section{Conclusions}

Two hundred $\mathrm{mg} / \mathrm{kg}$ curcumin dose, $400 \mathrm{mg} / \mathrm{kg}$ curcumin dose, and $200 \mathrm{mg} / \mathrm{kg}$ curcumin and vitamin D dose can increase
Table 3. Comparison of the percentage rate of increase in mean CAMP gene mRNA expression in the observation group before the intervention ( $4^{\text {th }}$ day), after the intervention $\left(10^{\text {th }}\right.$ day) and 3 weeks after the intervention ( $30^{\text {th }}$ day).

\begin{tabular}{lcc} 
Groups & $\begin{array}{c}\text { Percentage of mRNA gen CAMP expression } \\
\text { (fold change) } \\
\left(1^{\text {th }}-4^{\text {th }} \text { day }\right) *\left(30^{\text {th }}-10 \text { th day }\right) * *\end{array}$ \\
CM200 & 25 & 3.1 \\
CM400 & 50.9 & 1.8 \\
\hline CM200+Vit.D & 68.1 & 0.4 \\
Positive control & 57 & -0.4 \\
\hline Negative control & 8.2 & 6.8
\end{tabular}

*Average increase velocity=mean $\left(10^{\text {th }}-4^{\text {th }}\right.$ day $) 100 /$ mean $4^{\text {th }}$ day; ${ }^{* *}$ Average increase velocity=mean $\left(30^{\text {th }}-10^{\text {th }}\right.$ day) $100 /$ mean $10^{\text {th }}$ day.

\section{Levels of mRNA Gene CAMP expression (fold change)}

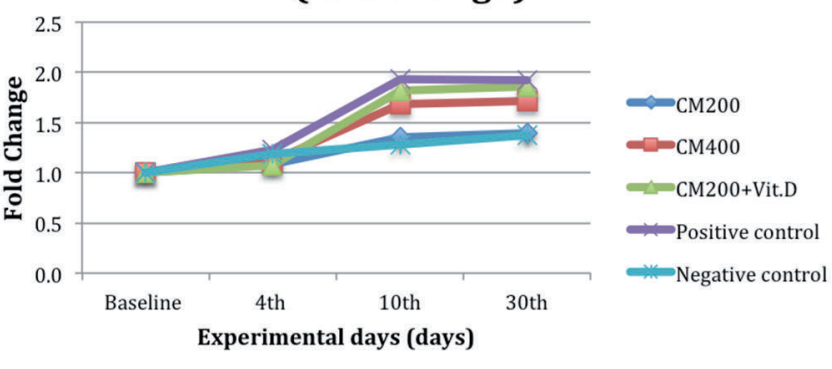

Figure 1. Dynamics of changes in levels of mRNA gena CAMP expression by the group during the observation period. 
the mRNA expression of CAMP gene after 5 days of intervention in mice. Our results support the evidence that curcumin and vitamin D have an antimicrobial effect that is induced by promoting CAMP mRNA expression.

\section{References}

1. Soedarmo SSP, Garna H, Hadinegoro SRS, et al. Indonesia Text Book of Tropical Infection in Pediatric, 2nd ed. Jakarta, Indonesia: Ikatan Dokter Anak Indonesia - Indonesian Pediatrics Assosciation, 2012.

2. Date KA, Adowa DBE, Fox KK, et al. Typhoid Fever surveillance and vaccine use - South-East Asia and Western pacific regions, 2009-2013. MMWR Morb Mortal Wkly Rep 2014; 63:855-60.

3. Ochiai RL, Acosta CJ, Donovaro-Holliday MC, et al. A study of typhoid fever in five Asian countries: disease burden and implications for controls. Bull World Health Organ 2008;86: 260-268.

4. Robertson RPL, Wahab MF, Raasch FO. Evaluation of Chloramphenicol and Ampicillin in Salmonella Enteric Fever. N Engl J Med 1968;278:171-6.

5. Butler T, Rumans L, Arnold K. Response of typhoid fever caused by chloramphenicol-susceptible and chloramphenicolresistant strains of Salmonella typhi to treatment with trimethoprim-sulfamethoxazole. Rev Infect Dis 1982;4:551-61.

6. Lampe RM, Duangmani C, Mansuwan P. Chloramphenicoland ampicillin-resistant typhoid fever. JAMA 1975;233:768.

7. Crump JA, Mintz ED. Global trends in typhoid and paratyphoid fever. Clin Infect Dis 2010;50:241-6.

8. Kariuki S, Revathi G, Kiiru J, Mengo D. Typhoid in Kenya is associated with a dominant multidrug-resistant Salmonella enterica serovar Typhi haplotype that is also widespread in Southeast Asia. J Clin Microbiol 2010;48:2171-6.

9. Dolecek C, Tran TPL, Nguyen NR, et al. A multi-center randomised controlled trial of gatifloxacin versus azithromycin for the treatment of uncomplicated typhoid fever in children and adults in Vietnam. PLoS One 2008;3:e2188.

10. Kumar Y, Sharma A, Mani K. High Level of Resistance to nalidixic acid in Salmonella enterica serovar Typhi in Central India. J Infect Dev Ctries 2009;3:467-9.

11. Dong BQ, Yiang J, Wang XY, et al. Trends and disease burden of enteric fever in Guangxi province, China, 1994-2004. Bull World Health Organ 2010;88:689-96.

12. Hatta M, Ranawati. Enteric fever in endemic areas of Indonesia: an increasing problem of resistance. J Infect Dev Ctries 2008;2:279-82.
13. Guo C, Rosoha E, Lowry MB, et al. Curcumin induces human cathelicidin antimicrobial peptide gene expression through a vitamin D receptor-independent pathway. J Nutr Biochem 2013;24:754-9.

14. Zanetti M. Cathelicidins, multifunctional peptides of the innate immunity. J Leukoc Biol 2004;75:39-48.

15. Zaiou M, Nizet V, Gallo RL. Antimicrobial and protease inhibitory functions of the human cathelicidin (hCAP18/LL37) prosequence. J Invest Dermatol 2003;120:810-6.

16. Sirait RH, Hatta M, Arief SK, et al. Profile of HMGB1 mRNA expression and TLR4 protein in BALB/c mice model sterile injury after systemic lidocaine administration. Pharmacogn J 2018;10:586-9.

17. Zhang S, Kingsley RA, Santos RL, et al. Molecular pathogenesis of Salmonella enterica serotype typhimurium-induced diarrhea. Infect Immun 2003;71:1-12.

18. Lamont RJ (ed). Bacterial Invasion of Host Cells. Cambridge University press; 2004.

19. Nizet V, Gallo RL. Cathelicidins and innate defense against invasive bacterial infection. Scand J Infect Dis 2003;35:670-6.

20. Brogden KA. Antimicrobial peptides: pore formers or metabolic inhibitors in bacteria? Nat Rev Microbiol 2005;3:238-50.

21. Wu H, Zhang G, Minton JE, et al. Regulation of cathelicidin gene expression: induction by lipopolysaccharide, interleukin6 , retinoic acid, and Salmonella enterica serovar typhimurium infection. Infect Immun 2000;68:5552-8.

22. Gombart AF, Borregaard N, Koeffler HP. Human cathelicidin antimicrobial peptide (CAMP) gene is a direct target of the vitamin D receptor and is strongl;19:1067-77.

23. Hase K, Eckmann L, Leopard JD, et al. Cell differentiation is a key determinant of cathelicidin LL-37/human cationic antimicrobial protein 18 expression by human colon epithelium. Infect Immun 2002;70:953-63.

24. Yesil S, Tanyildiz HG, Tekgunduz SA, et al. Vitamin D receptor polymorphisms in immune thrombocytopenic purpura. Pediatr Int 2017;59:682-5.

25. Hayes CE, Nashold FE, Spach KM, Pedersen LB. The immunological functions of the vitamin $\mathrm{D}$ endocrine system. Cell Mol Biol (Noisy-le-grand) 2003;49:277-300.

26. Hata TR, Kotol P, Jakson M, et al. Administration of oral vitamin $\mathrm{D}$ induces cathelicidin production in atopic individuals. $\mathrm{J}$ Allergy Clin Immunol 2008;122:829-31.

27. Gombart AF, Bhan I, Borregaar N, et al. Low plasma level of cathelicidin antimicrobial peptide (hCAP18) predicts increased infectious disease mortality in patients undergoing hemodialysis. Clin Infect Dis 2009;48:418-24.

28. Jeng L, Yamshchikov AV, Judd SE, et al. Alterations in vitamin $\mathrm{D}$ status and anti-microbial peptide levels in patients in the intensive care unit with sepsis. J Transl Med 2009;7:28. 